\title{
Undergraduate Critical Care Nursing Students' Knowledge And Attitudes Toward Caring Of Dying Patients
}

\author{
Suad Elsayed Elsaman PhD,RN \\ Department of Critical Care and Emergency Nursing, Faculty of Nursing, Alexandria University, Alexandria, \\ Egypt.
}

\begin{abstract}
Background Growth in the request for superiority end of life care have got palliative care (PC) emphasized as a national urgency, as well as the increasing prevalent provision of end of life care by nurses in critical care units. One of the important reasons inducing a successful provision of PC is nurses' knowledge and attitudes. So, there is a need to support and educate undergraduate critical care nursing students (UCCNSs) for obtaining high quality PC. The initial stage in formulating a strategy to educate UCCNSs about PC is to examine their current knowledge and attitudes.

Objective to examine UCCNSs' knowledge and attitudes toward caring of dying patients.

Method 184 UCCNSs participated in the study. The students attended and studied critical care nursing II course during the period from September till January 2015. All students were studying emergency nursing, critical care nursing I and II courses. Also, they were trained in the same clinical areas during their studying these courses. Two instrument were used to describe knowledge and attitudes level, Palliative Care Quiz for Nursing (PCQN) \& "Frommelt Attitude Toward the Care of the Dying Scale form B (FATCOD-B)"

Results Nearly two thirds (76.1\%) of UCCNSs had poor knowledge level and the majority (82.61\%) had fair total attitude score toward dying patients. Significant relationship between UCCNSs who reported having previous experiences with dying people and their total knowledge score. No significant relation between UCCNSs' attitude and their knowledge level.
\end{abstract}

Conclusions Most of UCCNSs lack some knowledge about PC but their attitude towards PC was fair. Combination of PC education within critical care nursing course is required.

Key words: Palliative care; Undergraduate student; critical nursing; knowledge; attitudes.

\section{Introduction}

Palliative care (PC) is usually seen as being the care of a patient who is near to death. In latest years, expression of PC has developed to include patients who can live for several years with end stage organ failure. According to World Health Organization (WHO), PC is a method that improves the quality of life of patients and their relatives fronting a problem linked with life threatening disease through avoidance and decreasing the suffering by means of early detection, perfect evaluation and treatment of pain and other problems physical and nonphysical. ${ }^{(1-3)}$

Palliative care is, and will remain to be, a vital part of nursing duties. Nurses are the most appreciated PC team members who are involved in the physical, functional, social, and spiritual scopes of care. Normally, when working in the health care field, death of a patient is encountered and specifically, most patients die in critical care units. Therefore, critical care nurses (CCNs) play an essential part in palliative and end-of-life care and they are answerable for knowing how to care for dying patients properly. ${ }^{(4-6)}$

Although there is an indication supporting the value of $\mathrm{PC}$, the number of health care professionals available to provide PC is insufficient to fulfill needs of patients and their relatives through lifetime, the illness path and health care settings. An important factor influence a successful delivery of PC is nurses' knowledge, and attitudes for providing care to dying patients. ${ }^{(7,8)}$

Attitudes of nurses affect restoration and self- approval of individuals with disabilities. So if negative attitudes believed by nurses about patients with disabilities, it may affect care that patient obtains. Although these attitudes are usually not clearly aggressive, they may result in patients with disabilities not getting suitable management or the designated protective care. As a result, identifying students' attitudes toward PC is of great importance because attitudes forecast future behavior. ${ }^{(9,10)}$

As part of the American Association of Colleges of Nursing (AACN) Essentials of Baccalaureate Education and the Peaceful Death document, specific goals and guidelines are outlined to ensure competency in PC prior to graduation. ${ }^{(11,12)}$ According to Beckstrand et al. $(2005)^{(13)}$ severe shortages in end-of-life care in 
critical care units remain to occur. This is a world-wide problem due in part to a lack of nursing education on end-of-life care. ${ }^{(14)} \mathrm{PC}$ information accounts for only $2 \%$ of content found in textbooks. Moreover, Content on end of life in critical care textbooks, both medical and nursing, is minimal. The first textbook on end of life in critical care was only published in 1998 and the second in 2001. ${ }^{(15-17)}$

The value of PC to CCNs who deliver majority of care to terminally ill patients is unquestionable, Studies have been done in the past to examine nurses' attitudes towards care of the dying, but little research has been done focusing specifically on CCNs. ${ }^{(18-20)}$ Moreover, a number of authors discussed the lack of research into student nurses' attitudes toward disabled people. SO, there is a need to support and educate undergraduate critical care nursing students (UCCNSs) for the provision of high quality PC. ${ }^{(21-23)}$ Hence, the first step in developing a strategy to educate UCCNSs about PC is to examine their current knowledge and attitudes. Therefore, this study aims to examine UCCNSs' knowledge and attitudes toward caring of dying patients.

\section{Aim of the Research}

To examine undergraduate critical care nursing students' knowledge and attitudes toward caring of dying patients.

\section{Research questions}

- What are the undergraduate critical care nursing students' attitudes to caring of dying as measured by the FATCOD scale?

- What is the undergraduate critical care nursing students' knowledge level about caring of dying patients as measured by the PCQN questionnaire?

\section{Research design:}

\section{Materials and Method}

A descriptive design was used.

\section{Setting:}

This study was achieved at Critical Care \& Emergency Nursing Department, Faculty of Nursing, Alexandria University, Egypt.

\section{Subjects:}

The undergraduate critical care nursing students $(\mathrm{N}=200)$ who joined critical care nursing II course were invited to participate during the period from September till January 2015. All students were studying courses of emergency nursing, critical care nursing I and critical care nursing II. Also, they practiced training in same practical areas during joining these courses. Of the total undergraduate critical care nursing students, 194 students decided to participate in the study and properly accomplished the questionnaire. Pilot study was done with 10 students who were excepted from the study so the sample became 184 students.

Tool: "Students' knowledge and attitudes assessment tool": structured interview schedule about undergraduate critical care nursing students' knowledge and attitudes toward caring of dying patients. It consists of three parts:

Part I: "Palliative Care Quiz for Nursing (PCQN)". It is a self-administered questionnaire developed by ROSS MM, McDonald B and McGuinness J. ${ }^{(24,25)}$ It consist of 20 items that are distributed according to conceptual category of content as follows (a) philosophy and principles of palliative care $(n=4)$, (b) management of pain and other symptoms $(n=13)$, and $(c)$ psychosocial aspects of care $(n=3)$. The questionnaire was used to assess knowledge of nurses toward caring of dying patient. The knowledge was assessed as follows: each question had four answering opinions; correct that was graded one, incorrect or I don't know that were graded zero. Correct answers were grouped to get a final score for each student. Full score for all questions was 20 grades. The knowledge scores were classified into Poor knowledge $(<50 \%)$, Fair knowledge $(50-<75 \%)$, and $(\geq 75 \%)$ considered Good knowledge.

Part II: "Frommelt Attitude Toward the Care of the Dying Scale form B (FATCOD-B)" that is a psychometric instrument, developed by Frommelt ${ }^{(26,27)}$ and is translated in to Arabic by the researcher. The scale is designed to measure nurses' attitudes toward caring for terminally ill persons and their families. There are three forms of the scale are available: form 0 is the original form with 20 items; form A and B, with 30 items, are improved 
versions of form 0. The FATCOD- B scale is self-report paper and pencil questionnaire consists of 30 randomly ordered items in which the participant is asked to indicate his or her level of agreement, ranging from agree to disagree. Two thirds of the items relate directly to nurses' attitudes toward the dying patient and one third of the items relate directly to nurses' attitudes toward the patient's family members. The items are grouped into items of cognitive domain (12 items), items of affective domains (9 items) and items of dying patient's family (9 items). The FATCOD- B instrument consists of 30 Likert type items that are scored on a 3point scale: from 1 (disagree), 2 (uncertain), to 3 (agree). Fifteen of the items are worded positively and 15 are worded negatively. Scoring is reversed for the negative items. Thus, possible scores range from 0 to 90 , with higher scores representing more positive attitudes toward providing care for dying patients. The attitude scores were categorized into Poor $(<50 \%)$, Fair $(50-<75 \%)$, and good $(\geq 75 \%)$.

In addition to data concerning demographic aspects and characteristics of age, sex, and having past experience of dealing with dying patient will be gained.

\section{Method}

An official approval was obtained from "head of Critical Care \& Emergency Nursing Department", and "Nursing Ethical Committee" of Nursing Faculty- Alexandria University. Part II "FATCOD-B" was interpreted to Arabic by the researcher after reviewing the related literatures. ${ }^{(28,29)}$ The tool was tested for content validity and translation by experts in the field of critical care and nursing education and necessary adjustments were done (e.g. modifications related to Arabic translation). The reliability was done using Cronbach's alpha test and the result for PCQN was 0.964 and for FATCOD-B was 0.977. Explaining study aim for students was done and the written consent to join was obtained. The anonymity and confidentiality of replies, considered involvement and right to refuse to join to study were highlighted to students.

A pilot study was done on a sample of ten learners who were chosen randomly to establish the clarity and applicability of the tool and the required adjustments were done. The learners were gathered into six clusters each cluster includes 30 learners and it was interviewed once with the tool by the researcher. Each meeting lasted from 20 to 30 minutes.

\section{Statistical analysis of the data ${ }^{(30)}$}

Data were served to computer and analyzed using IBM SPSS software package version 20. (31) Qualitative data were designated by means of number and percent. Quantitative data were designated by means of mean and standard deviation. Comparison between two independent population were done using independent t-test while more than two population were analyzed F-test. Correlations between two quantitative variables were assessed using Pearson coefficient. Reliability Statistics was assessed using Cronbach's Alpha test, and validity test using Pearson coefficient. Significance was judged at $\leq 0.05$ level.

\section{Results}

Table (1) shows socio-demographic data of the studied undergraduate critical care nursing students (UCCNSs) as the majority of the UCCNSs were females (71.7\%), aged from 21 to 22 years old $(66.3 \%)$ and nearly two third of the studied UCCNSs had past experience in dealing with dying patients $(65.2 \%)$.

Table (1): Socio-demographic data of the students $(\mathrm{N}=184)$

\begin{tabular}{||l|c|c||}
\hline \multicolumn{1}{|c|}{ Socio-demographic data } & No. & $\%$ \\
\hline Gender & & \\
\hline
\end{tabular}




\begin{tabular}{|c|c|c|}
\hline $\begin{array}{l}\text { Female } \\
\text { Male }\end{array}$ & $\begin{array}{c}132 \\
52\end{array}$ & $\begin{array}{l}71.7 \\
28.3\end{array}$ \\
\hline $\begin{array}{l}\text { Age (years) } \\
<21 \\
21-22 \\
>22\end{array}$ & $\begin{array}{c}27 \\
122 \\
35\end{array}$ & $\begin{array}{c}14.7 \\
66.3 \\
19\end{array}$ \\
\hline $\begin{array}{l}\text { Min. - Max. } \\
\text { Mean } \pm \text { SD }\end{array}$ & & \\
\hline $\begin{array}{l}\text { Had past experience in dealing with dying patients } \\
\text { Yes } \\
\text { No }\end{array}$ & $\begin{array}{c}120 \\
64\end{array}$ & $\begin{array}{l}65.2 \\
34.8\end{array}$ \\
\hline
\end{tabular}

Table (2) shows Distribution of the studied UCCNSs according to their level of knowledge by means of Palliative Care Quiz for Nursing Scale (PCQN). It reveals that about two thirds of studied UCCNSs (76.1\%) had poor level and nearby one quarter of the studied UCCNSs (22.28) had fair level of knowledge regard caring of dying patients with Mean \pm SD $(7.35 \pm 3.22)$.

Table (2): Distribution of the studied UCCNSs according to their level of knowledge using Palliative Care Quiz for Nursing Scale (PCQN).

\begin{tabular}{|c|c|c|}
\hline \multirow{2}{*}{ PCQN Scale } & \multicolumn{2}{|c|}{ UCCNSs $(\mathrm{No}=\mathbf{1 8 4})$} \\
\hline & No. & $\%$ \\
\hline \multicolumn{3}{|l|}{ Levels related to total scoring } \\
\hline Poor $(<50 \%)$ & 140 & 76.1 \\
\hline Fair $(50-<75 \%)$ & 41 & 22.28 \\
\hline Good $(\geq 75 \%)$ & 3 & 1.63 \\
\hline \multicolumn{3}{|l|}{ Total score } \\
\hline Min. - Max. & \multirow{2}{*}{\multicolumn{2}{|c|}{$\begin{array}{c}0-17 \\
7.35 \pm 3.222\end{array}$}} \\
\hline Mean \pm SD & & \\
\hline
\end{tabular}

Table (3) shows UCCNSs' description of their attitudes based on FATCOD-B items (items of cognitive domain) which include that large percentage of students $(79.3 \%)$ had a positive attitude toward dying patients as they agreed that giving nursing care to the dying persons is a worthwhile learning experience. Nearly half of the studied UCCNSs (57.6\%) agree that the nurse should not be the one to talk about death with the dying person and death is not the worst thing that can happen to a person. More than half of the studied UCCNSs (65.8\% and 68.5\%) agree that it is beneficial for dying person to express his feelings and also nurse should allow dying persons to have flexible visiting plans. In the opposite side, more than half $(60.3 \%)$ of the studied UCCNSs disagreed that dying persons should be given truthful responses about their condition.

Table (3): Description of the studied UCCNSs' attitudes based on FATCOD-B items (items of cognitive domain)

\begin{tabular}{||c|c|c|c|}
\hline Item & Agree & Uncertain & Disagree \\
\hline - Giving care to the dying person is a worthwhile & $146(79.3)$ & $30(16.3)$ & $8(4.3)$ \\
\hline
\end{tabular}




\begin{tabular}{||l|l|l|l||}
\hline experience. & & & \\
\hline $\begin{array}{l}\text { - The nurse should not be the one to talk about death with } \\
\text { the dying person. }\end{array}$ & $106(57.6)$ & $55(29.9)$ & $23(12.5)$ \\
\hline - Death is not the worst thing that can happen to a person. & $106(57.6)$ & $47(25.5)$ & $31(16.8)$ \\
\hline $\begin{array}{l}\text { - It is beneficial for the dying person to verbalize his/her } \\
\text { feelings. }\end{array}$ & $121(65.8)$ & $48(26.1)$ & $15(8.2)$ \\
\hline $\begin{array}{l}\text { - Addiction to pain relieving medication should not be a } \\
\text { concern when dealing with a dying person. }\end{array}$ & $113(61.4)$ & $53(28.8)$ & $18(9.8)$ \\
\hline $\begin{array}{l}\text { - The dying person should not be allowed to make } \\
\text { decisions about his/her physical care }\end{array}$ & $91(49.5)$ & $55(29.9)$ & $38(20.7)$ \\
\hline $\begin{array}{l}\text { - Dying persons should be given honest answers about } \\
\text { their condition. }\end{array}$ & $19(10.3)$ & $54(29.3)$ & $111(60.3)$ \\
\hline \begin{tabular}{l} 
- It is possible for nurse to help patients prepare for death. \\
\hline - There are times when the dying person welcomes death.
\end{tabular} & $100(54.3)$ & $51(27.7)$ & $33(17.9)$ \\
\hline $\begin{array}{l}\text { - When a patient asks, “Am I dying?" I think it is best to } \\
\text { change the subject to something cheerful. }\end{array}$ & $98(53.3)$ & $51(33.2)$ & $21(11.4)$ \\
\hline $\begin{array}{c}\text { - As a patient nears death, the nurse should withdraw } \\
\text { from his/her involvement with the patient. }\end{array}$ & $77(41.8)$ & $53(28.8)$ & $54(29.3)$ \\
\hline $\begin{array}{l}\text { - Nurse should permit dying persons to have flexible } \\
\text { visiting schedules. }\end{array}$ & $126(68.5)$ & $40(21.7)$ & $18(9.8)$ \\
\hline
\end{tabular}

Table (4) shows the studied UCCNSs' description of their attitudes based on FATCOD-B items (items of affective domain) which include that negative attitudes are expressed by some of the studied UCCNSs (56.5, 50, 52.2, and 73.4) as they agree that the nurse would not want to care for a dying person, the length of time required giving care to a dying person would frustrate the nurses. The nurses would hope the person they are caring for dies when they aren't present and the nurses are afraid to become friends with a dying person. On the other hand, the studied UCCNSs' attitudes varied from agree to disagree $(61.4 \%$ and $16.8 \%)$ regarding the nurses would be uncomfortable talking about impending death with the dying person. More than half (64.1\%) of the studied UCCNSs agree that the nurse would be uncomfortable if he or she entered the room of a terminally ill person and found him/her crying.

Table (4): Description of the studied UCCNSs' attitudes based on FATCOD-B items (items of affective domain)

\begin{tabular}{|c|c|c|c|}
\hline \multicolumn{1}{|c|}{ Item } & Agree & Uncertain & Disagree \\
\hline$-\quad \begin{array}{l}\text { I would be uncomfortable talking about impending } \\
\text { death with the dying person. }\end{array}$ & $113(61.4)$ & $40(21.7)$ & $31(16.8)$ \\
\hline$-\quad$ I would not want to care for a dying person & $104(56.5)$ & $54(29.3)$ & $26(14.1)$ \\
\hline$-\quad \begin{array}{l}\text { The length of time required giving care to a dying person } \\
\text { would frustrate me. }\end{array}$ & $92(50)$ & $55(29.9)$ & $37(20.1)$ \\
\hline $\begin{array}{l}\text { I would be upset when the dying person I was caring for } \\
\text { gave up hope of getting better. }\end{array}$ & $103(56)$ & $55(29.9)$ & $26(14.1)$ \\
\hline $\begin{array}{l}\text { It is difficult to form a close relationship with the dying } \\
\text { person }\end{array}$ & $76(41.3)$ & $66(35.9)$ & $42(22.8)$ \\
\hline $\begin{array}{l}\text { - I would hope the person I'm caring for dies when I am not } \\
\text { present. }\end{array}$ & $96(52.2)$ & $53(28.8)$ & $35(19)$ \\
\hline- I am afraid to become friends with a dying person & $135(73.4)$ & $28(15.2)$ & $21(11.4)$ \\
\hline $\begin{array}{l}\text { - I would feel like running away when the person actually } \\
\text { died }\end{array}$ & $69(37.5)$ & $71(38.6)$ & $44(23.9)$ \\
\hline $\begin{array}{l}\text { - I would be uncomfortable if I entered the room of } \\
\text { a terminally ill person and found him/her crying }\end{array}$ & $118(64.1)$ & $46(25)$ & $20(10.9)$ \\
\hline
\end{tabular}

Table (5) demonstrates the studied UCCNSs' description of their attitudes based on FATCOD-B items (items of dying patient's family) which include that the majority of the studied UCCNSs had positive attitudes as $73.9 \%$ and $74.5 \%$ of the students agreed that families need emotional support to accept the behavior changes of the dying person and families should be concerned about helping their dying member make the best of his/her remaining life. Additionally, positive attitudes are demonstrated by approximately two third of the studied 
UCCNSs $(66.3,67.4,65.2,67.4$, and $63 \%)$ who agreed that nursing care for the patient's family should continue throughout the period of grief and bereavement, the family should be involved in the physical care of the dying person, Families should maintain as normal an environment as possible for their dying member, Care should extend to the family of the dying person and The dying person and his/her family should be the in-charge decision-makers respectively. On the other hand nearly half of the studied UCCNSs had a negative attitude $(52.2 \%$ and $57.1 \%)$ as they agreed that educating families about death and dying is not a nonfamily caregiver responsibility, and family members who stay close to a dying person often interfere with the professional's job with the patient respectively.

Table (5): Description of the studied UCCNSs' attitudes based on FATCOD-B items (items of dying patient's family)

\begin{tabular}{|c|c|c|c|}
\hline Item & Agree & Uncertain & Disagree \\
\hline $\begin{array}{l}\text { - Caring for the patient's family should continue throughout } \\
\text { the period of grief and bereavement. }\end{array}$ & $122(66.3)$ & $42(22.8)$ & 20(10.9) \\
\hline $\begin{array}{l}\text { - The family should be involved in the physical care of the } \\
\text { dying person. }\end{array}$ & $124(67.4)$ & $38(20.7)$ & $22(12)$ \\
\hline $\begin{array}{l}\text { - Families need emotional support to accept the behavior } \\
\text { changes of the dying person }\end{array}$ & $136(73.9)$ & $31(16.8)$ & $17(9.2)$ \\
\hline $\begin{array}{l}\text { - Families should be concerned about helping their dying } \\
\text { member make the best of his/her remaining life. }\end{array}$ & $137(74.5)$ & $36(19.6)$ & $11(6)$ \\
\hline $\begin{array}{l}\text { - Families should maintain as normal an environment as } \\
\text { possible for their dying member. }\end{array}$ & $120(65.2)$ & $51(27.7)$ & $13(7.1)$ \\
\hline - Care should extend to the family of the dying person. & $124(67.4)$ & $42(22.8)$ & $18(9.8)$ \\
\hline $\begin{array}{l}\text { - The dying person and his/her family should be the in- } \\
\text { charge decision-makers. }\end{array}$ & $116(63)$ & $46(25)$ & $22(12)$ \\
\hline $\begin{array}{l}\text { - Educating families about death and dying is not a nurse } \\
\text { responsibility }\end{array}$ & $96(52.2)$ & $52(28.3)$ & $36(19.6)$ \\
\hline $\begin{array}{l}\text { - Family members who stay close to a dying person often } \\
\text { interfere with the professional's job with the patient }\end{array}$ & $105(57.1)$ & $54(29.3)$ & 25(13.6) \\
\hline
\end{tabular}

Table (6) reveals that the majority of the studied UCCNSs $(82.61 \%)$ had fair attitude regards caring of dying patients with Mean \pm SD $62.85 \pm 4.858$

Table (6): Distribution of the studied UCCNSs according to their attitudes level using Frommelt Attitude toward the Care of the Dying Scale form B (FATCOD-B).

\begin{tabular}{|c|c|c|}
\hline \multirow{2}{*}{ FATCOD-B Scale } & \multicolumn{2}{|c|}{ CCNS $($ No $=184)$} \\
\hline & No. & $\%$ \\
\hline $\begin{array}{l}\text { Levels related to total scoring } \\
\text { Poor }(<50 \%) \\
\text { Fair }(50-<75 \%) \\
\text { Good }(\geq 75 \%)\end{array}$ & $\begin{array}{c}0 \\
160 \\
24 \\
\end{array}$ & $\begin{array}{c}0 \\
86.96 \\
13.04 \\
\end{array}$ \\
\hline $\begin{array}{l}\text { Total score } \\
\text { Min. }- \text { Max. } \\
\text { Mean } \pm \text { SD }\end{array}$ & \multicolumn{2}{|c|}{$\begin{array}{c}50-77 \\
61.85 \pm 4.77\end{array}$} \\
\hline
\end{tabular}

Table (7) shows that no significant differences were found between the studied UCCNSs' age and sex and their total knowledge score $(\mathrm{P}=0.422$ and 0.70 respectively) or their total attitudes score $(\mathrm{P}=0.417$ and 0.881 respectively). In relation to having previous experiences with dying people, A statistical significant difference exists between the studied UCCNSs who reported they had previous experiences with dying people $(\mathrm{P}=0.013)$ and their total knowledge score and no significant difference with their total attitudes score $(\mathrm{P}=$ $0.548)$.

Table (7): The relation between the studied UCCNSs' demographic data and their total knowledge and attitudes scores.

\begin{tabular}{|c|c|c|c|}
\hline Variables & $\mathrm{N}$ & $\begin{array}{c}\text { Total knowledge score } \\
(\text { Mean } \pm \text { SD) }\end{array}$ & $\begin{array}{c}\text { Total Attitude score } \\
(\text { Mean } \pm \text { SD) }\end{array}$ \\
\hline
\end{tabular}


Undergraduate Critical Care Nursing Students' Knowledge and Attitudes toward Caring of Dying...

\begin{tabular}{|c|c|c|c|}
\hline Age (years) & & & \\
\hline$<21$ & 27 & $6.70 \pm 2.826$ & $60.96 \pm 4.12$ \\
\hline $21-22$ & 122 & $7.56 \pm 3.265$ & $62.17 \pm 5.05$ \\
\hline$>22$ & 35 & $7.14 \pm 3.362$ & $61.43 \pm 4.19$ \\
\hline Test of significance & & $\mathrm{F}=0.867 \quad \mathrm{P}=(0.422)$ & $\mathrm{F}=.879 \quad \mathrm{P}=(0.417)$ \\
\hline \multicolumn{4}{|l|}{ Sex } \\
\hline Male & 52 & $8.04 \pm 3.162$ & $61.77 \pm 4.25$ \\
\hline Female & 132 & $7.08 \pm 3.217$ & $61.89 \pm 4.98$ \\
\hline Test of significance $(\mathbf{P})$ & & $\mathrm{t}=1.822 \mathrm{P}=(0.070)$ & $\mathrm{t}=0.149 \mathrm{P}=(0.881)$ \\
\hline \multicolumn{4}{|l|}{$\begin{array}{l}\text { Have previous experience with } \\
\text { dying patient }\end{array}$} \\
\hline No & 64 & $6.55 \pm 3.034$ & $61.56 \pm 4.74$ \\
\hline Yes & 120 & $7.78 \pm 3.249$ & $62.01 \pm 4.80$ \\
\hline Test of significance $(\mathrm{P})$ & & $\mathrm{t}=-2.515 \mathrm{P}=(0.013)^{*}$ & $\mathrm{t}=-0.602 \quad \mathrm{P}=(0.548)$ \\
\hline
\end{tabular}

* $\mathrm{P}$ is significant if $\leq 0.05$

Table (8) shows that there is no correlation between the studied UCCNSs' total knowledge score and total attitude score $(\mathrm{P}=\mathbf{0 . 9 0 1})$.

Table (8): The correlation between the studied UCCNSs' total knowledge scores and their total attitude scores.

\begin{tabular}{||c|c|c|}
\hline Scales & $\mathbf{R}$ & $\mathbf{p}$ \\
\hline Total knowledge score vs Total attitude score & $\mathbf{- 0 . 0 2 6}$ & $\mathbf{0 . 7 2 5}$ \\
\hline
\end{tabular}

$* \mathrm{P}$ is significant if $\leq 0.05$

\section{Discussion}

Critical care nurses are the most vital first contacts of seriously terminally ill patients in intensive care units. It is essential first to create undergraduate critical care nursing students' (UCCNSs) baseline knowledge because knowledge shows a fundamental role in attitude or behavioral consistency so that appropriate educational programs can be introduced. ${ }^{(32-34)}$

The current study illustrated that nearly two third of the UCCNSs had past experience in dealing with dying patients. This is due to that UCCNSs were trained in critical care units all over the clinical rotations where there were chances to have experience in dealing with dying patients.

In addition, the current study revealed that nearly two thirds of the UCCNSs had poor level of knowledge. This finding could be attributed to that lack of educational training on death and care of dying through basic nursing courses. Sadhu et al. $(2010)^{(35)}$ reported that student nurses infrequently have experience with the dying people due to faculty viewing these cases as undesirable and as "not good teaching cases".

Moreover, Frommelt (1991) ${ }^{(27)}$ found $76.5 \%$ of the study nurses felt inadequately prepared to care for the terminally ill. Also, Kuebler et al. $(2012)^{(36)}$ have found that not all nurses are knowledgeable about the care needed for a dying patient. ${ }^{(37)}$

Nursing schools have not adequately incorporated palliative care into the curriculum to increase awareness of PC content and skills. ${ }^{(35)}$ According to Mallory (2003) ${ }^{(4)}$, nursing education has historically lacked an effective approach toward providing education on end-of-life care. ${ }^{(38,39)}$

The present results demonstrated that positive attitudes toward dying patients are expressed by the majority of the UCCNSs as they agreed that giving nursing care to the dying persons is a worthwhile learning experience. These results may be related to the students' values and intrinsic religious beliefs. Dunn et al. $(2005)^{(40)}$ and Kock (2011) ${ }^{(41)}$ in their study about nurses' attitude toward dying patients revealed that most participants demonstrated a positive attitude about providing care for dying patients. ${ }^{(42)}$

Additionally, the current study showed that in the opposite side, more than half of the UCCNSs addressed psychological issues of the patient by hiding the truth as they disagreed that dying persons should be 
given honest answers about their condition. In contrary, Lorensen M et al. (2003) ${ }^{(43)}$ reported that majority of nurses viewed that lying to the patients about their diagnosis and prognosis as unethical.

On the other hand, the current study revealed that the negative attitudes are expressed by nearly half the UCCNSs as they agree that the nurse would not want to care for a dying person, the length of time required giving care to a dying person would frustrate the nurses. The nurses would hope the person they are caring for dies when they aren't present and the nurses are afraid to become friends with a dying person. These findings could be attributed to that UCCNSs exposed to dying patients, but lacking education in how to care for the dying, experienced death anxiety and negative attitudes toward care of the dying and eventually withdraw from caring for the dying. Sadhu et al. (2010) $)^{(35)}$ stated that "health care professionals function largely within a culture that focuses on cure, and many avoid the patient who is dying".

The positive attitudes toward caring of dying patient's family are shown in the present finding as nearly two third of the UCCNSs agreed that families need emotional support to accept the behavior changes of the dying person and families should be concerned about helping their dying member make the best of his/her remaining life. Kock $(2011)^{(41)}$ revealed that most of the study nurses agreed that families need emotional support. ${ }^{(44,45)}$

On the other hand nearly half of the UCCNSs had a negative attitude as they disagreed that educating families of dying patients about death and dying is nursing responsibility. This result may be attributed to students' feelings of anxiety and being uncomfortable to talk about death. Ali $(2010)^{(46)}$ found that study nurses were unlikely to talk with or even educate dying patients or their families about death. While, Dunn et al. $(2005)^{(40)}$ and Kock $(2011)^{(41)}$ revealed that the study nurses agreed that educating families of dying patients about death and dying is a nursing responsibility.

In the current study, UCCNSs' attitude toward dying patients showed that the majority of the UCCNSs had fair total attitude score. This may be due to that the UCCNSs' acceptance of death as a fact of life as they view death as a natural part of life and also as a gateway to the afterlife. Abudari et al. (2014) ${ }^{(47)}$ and Dunn et al. $(2005)^{(40)}$ revealed that most participants demonstrated a positive attitude about providing care for dying patients. Furthermore, Kassa et al. $(2014)^{(2)}$ and , Karkada et al. $(2011)^{(48)}$ demonstrated that $(76 \%$ and $92.8 \%$ respectively) of the studied nurses had favorable attitude towards PC.

In the current study, there was significant statistical relationship exists between the UCCNSs who reported that they had previous experiences with dying people and their total knowledge score. It can be related to that UCCNSs' value education in PC, particularly clinical experience with patients and their families. Fashafsheh I. et al. $(2015)^{(49)}$ noticed a positive relationship between experience, qualification and training on palliative care and knowledge of nurses. ${ }^{(50)}$

The current study revealed that there is no statistical significant relationship exists between UCCNSs' age and their attitude and this result is supported by Wattanachote $(1997)^{(51)}$ who found that there is no significant correlation between the age and a nurse's caring behavior for dying patients.

Furthermore this study revealed that there is no significant relation between UCCNSs' attitude and their knowledge level. Mallory JL. (2003) ${ }^{(4)}$ Concluded that previous death education did not have an effect on attitudes toward care of the dying. On other hand, Frommelts $(1991)^{(27)}$ found that the only significant factor affecting nursing students attitudes toward care of the dying was previous education on death and dying. ${ }^{(52)}$

\section{Conclusion}

It is clear from these findings that most of the undergraduate critical care nursing students were inadequately prepared to care for terminally ill and dying patients as they had deficiency in some knowledge about palliative care but their attitude towards PC was fair

\section{Recommendations}

It is recommended to incorporate PC education within critical care nursing course to better prepare novel graduates for the inevitable care of a terminally ill patient.

\section{References}

[1] World Health Organization (WHO): WHO definition of palliative care. $2015 . \quad$ Available from: http://www.who.int/mediacentre/factsheets/fs402/en/. Retrieved date: 13 August, 2016.

[2] Kassa H, Murugan R, Zewdu F, Hailu M, Woldeyohannes D. Assessment of knowledge, attitude and practice and associated factors towards palliative care among nurses working in selected hospitals, Addis Ababa, Ethiopia. BMC Palliative Care. 2014; $13(6): 1-11$.

[3] Daniels D, John L. Contemporary medical surgical nursing. 2nd ed. Thomson Delmar Learing. 2012; 109-16.

DOI: 10.9790/1959-0601013140 $\quad$ www.iosrjournals.org $38 \mid$ Page


[4] Mallory JL. The Impact of a Palliative Care Educational Component on Attitudes Toward Care of the Dying in Undergraduate Nursing Students. Journal of Professional Nursing. 2003; 19(5): 305-12. http://dx.doi.org/10.1016/S8755-7223(03)00094-2

[5] Prompahakul C, Nilmanat K, Kongsuwan w. Factors Relating to Nurses' caring behaviors for dying Patients. Nurse Media Journal of Nursing. 2011; 1 (1):15-27.

[6] Morton P, Fontaine D. Critical care nursing a holistic approach. End of life issues in critical care. 9th ed. Wolters Kluwer health Lippincott Williams \&Wilkins, 2013; 70-81.

[7] Coyle N. Introduction to palliative nursing care. In Ferrell BR, Coyle N, Paice J (eds.), Oxford Textbook of Palliative Nursing. $4^{\text {th }}$ ed. New York, NY: Oxford University Press, 2015:3-10.

[8] American Nurses Association and Hospice and Palliative Nurses Association. Palliative Nursing: Scope and Standards of Practice-An Essential Resource for Hospice and Palliative Nurses. $5^{\text {th }}$ ed. Silver Spring, MD: American Nurses Association and Hospice and Palliative Nurses Association; 2013

[9] Uysal A, Albayrak B, Koçulu B, Kan F, Aydın T. Attitudes of nursing students toward people with disabilities. Nurse Education Today. 2014; 34: 878-84

[10] De Laat S, Freriksen E, Vervloed M.P.J. Attitudes of children and adolescents toward persons who are deaf, blind, paralyzed or intellectually disabled. Res. Dev. Disabil. 2013; 34: 855-63.

[11] Pope A. Palliative Care Knowledge among Bachelors of Science Nursing Students. Dissertations, Theses and Capstone Projects. 2013: 596.

[12] Hermann CP, Head BA, black K, Singleton K. Preparing nursing students for interprofessional practice: the interdisciplinary curriculum for oncology palliative care education. J Prof Nurs. 2016; 32: 62-71.

[13] Beckstrand R, Kirchhoff k. Providing end-of-life care to patients: Critical care nurses' perceived obstacles and supportive behaviors. American Journal of Critical Care. 2005; 14: 395-403.

[14] Abu Hasheesh M, AboZeid S, El-Said S, Alhujaili A. Nurses' characteristics and their Attitudes toward Death and Caring for Dying Patients in a Public Hospital in Jordan. Health and science journal. 2013; 4(70):384- 394.

[15] Dracup K, Christopher W. Dying in the Intensive Care Unit. Am J Crit Car. 2005; 14(6): 456-458.

[16] Ferrell B, Coyle N. Textbook of Palliative Nursing. 2nd ed. Oxford, NY: Oxford University Press; 2006.

[17] Urden L, Stacy K, Lough M. Critical care nursing diagnosis and management. End-of- Life Issues. 7th ed: California. Mosby, Elsevier, Inc. 2014; 182-99.

[18] Easom L, Galatas S. End-of-life care: an educational intervention for rural nurses in southeastern USA. International Journal of Palliative Nursing. 2006; 12(11): 526-534.

[19] Kirchhoff K, Beckstrand R. Critical care nurses' view of obstacles and helpful behaviors in providing end-of-life care to dying patients. Thesis dissertation, 2011: available at (cardinalscholar.bsu.edu/.../JonesF_2011-1_BODY.pdf) retrieved on: 21-4-2013.

[20] Gopal K S, Archana PS. Awareness, Knowledge and Attitude about Palliative Care, in General, Population and Health Care Professionals in Tertiary Care Hospital. International Journal of Scientific Study. January 2016; 3(10): 31-5.

[21] Seccombe JA. Attitudes towards disability in an undergraduate nursing curriculum: a literature review. Nurse Educ. Today. 2007b; 27(5):459-65

[22] Sahin H, Akyol DA . Evaluation of nursing and medical students' attitudes towards people with disabilities. J. Clin. Nurs. 2010; 19: 2271-9.

[23] Patricia A, Potter R, Hall A. Fundamentals of Nursing. The experience of loss, death and grief. 8th ed. Elsevier, 2013; 709-29.

[24] ROSS MM, McDonald B, McGuinness J. The palliative care quiz for nursing (PCQN): the development of an instrument to measure nurses' knowledge of palliative care. Journal of Advanced Nursing. 1996; 23: 126-37.

[25] Karacsony S, Chang E, Johnson A, Good A, Edenborough M. Review Measuring nursing assistants' knowledge, skills and attitudes in a palliative approach: A literature review. Nurse Education Today. 2015; 35: 1232-9.

[26] Leombruni P, Miniotti M, Bovero A, Zizzi1 F, Castelli L, Torta R. Attitudes toward caring for dying patients: An overview among Italian nursing students and preliminary psychometrics of the FATCOD-B scale. Journal of Nursing Education and Practice. 2014; 4(3): 188-96.

[27] Frommelt K. The effects of death education on nurses' attitudes toward caring for terminally ill persons and their families. The American Journal of Hospice and Palliative Care. 1991; 8(5), 37-43.

[28] Easom L, Galatas S. End-of-life care: an educational intervention for rural nurses in southeastern USA. International Journal of Palliative Nursing. 2006; 12(11): 526-534.

[29] Townsend M. Psychiatric mental health nursing: Concepts of care. (4 ${ }^{\text {th }}$ ed). Philadelphia: F. A. Davis Company, 2003.

[30] Kotz S, Balakrishnan N, Read CB, Vidakovic B. Encyclopedia of statistical sciences. 2nd ed. Hoboken, N.J.: Wiley-Interscience; 2006.

[31] Kirkpatrick LA, Feeney BC. A simple guide to IBM SPSS statistics for version 20.0. Student ed. Belmont, Calif.: Wadsworth, Cengage Learning; 2013.

[32] Temple B, Mordoch E. Nursing students perceptions of disability and preparation to care for people with intelledctual disabilities. J. Nurs. Educe. 2012; 51(7):407-10.

[33] Janice L, Kerry H. Text book of medical surgical nursing. End for life care. $13^{\text {th }}$ ed. Wolterskluwer, Lippincott. 2014; 373-399.

[34] Anderson WG, Puntillo K, Boyle D, Susan Barbour S, Turner K, Cimino J, Moore E, Noort J, MacMillan J, Pearson D, Grywalski M, Liao S, Ferrell B, Meyer J. Julia C, Herman H, Mitchell W, Pantilat S. ICU Bedside Nurses' Involvement in Palliative Care Communication: A Multicenter Survey. Journal of pain and symptom management. 2016; 51(3):589-96.

[35] Sadhu S, Salins NS, Kamath A. Palliative care awareness among Indian undergraduate health students: A needs-assessment study to determine incorporation of palliative care education in undergraduate medical, nursing, and allied health education. Indian Journal of Palliative Care. 2010; 16(3): 154-159. doi: 10.4103/0973- 075.73645.

[36] Kuebler, K. Implications for palliative care nursing education. Clinical Scholars Review. 2012; 5(2): 86-90. doi: 10.1891/19392095.5.2.86.

[37] Prem V., Karvannan H., Kumar S., Karthikbabu S., Syed N., Sisodia V., Jaykumar S.(2012). Study of Nurses' Knowledge about Palliative Care: A Quantitative Cross-sectional Survey. Indian Journal of Palliative Care. Vol 18 (2): 122-127

[38] Shimizu M, Nishimura M, Ishii Y, Kuramochi M, Kakuta N, Miyashita M. Development and validation of scales for attitudes, selfreported practices, difficulties and knowledge among home care nurses providing palliative care. European Journal of Oncology Nursing. 2016; 22: 8-22.

[39] Iranmanesh S., Razban F. , Tirgari B., Zahra G. Nurses' knowledge about palliative care in Southeast Iran. Palliative and Supportive Care. 2014; 12: 203-10.

[40] Dunn K, Stephens E. Nursing experience and the care of dying patients. ONCOLOGY NURSING FORUM. 2005; 1(32): 97-104. 
[41] Kock F. Factors influencing nurses' attitudes towards caring for dying patients in oncology settings in the Western Cape Metropole. Thesis dissertation, 2011: available at http://scholar.sun.ac.za/handle/10019.1/6753. Retrieved on $8-2016$.

[42] Coolen P. Cultural Relevance in End-of-Life Care. 2012. Available at https://ethnomed.org/clinical/end-of-life/cultural-relevance-inend-of-life-care.

[43] Lorensen M, Davis AJ, Konishi E, Bunch EH. Ethical issues after the disclosure of a terminal illness: Danish and Norwegian hospice nurses' reflections. Nurs Ethics. 2003; 10(2):175-185. 2

[44] Dockray H. Islamic Rituals for the Dying and Deceased. 2013. Available at http://christicenter.org/2013/03/islamic-rituals-dyingdeceased/. Retrieved on 10/ 2014.

[45] Bratcher R. How do critical care nurses define a "good death" in the intensive care unit? Critical Care Nursing Quarterly 2010; 33(1): 87-99.

[46] Ali W. Nurses' attitudes toward caring for dying patient in Mansoura university hospital. Journal of medicine and biomedical science. 2010; $16-20$.

[47] Abudari G., Zahreddine H., Hazeim H., Al Assi M., and Emara S. Knowledge of and attitudes towards palliative care among multinational nurses in Saudi Arabia. International Journal of Palliative Nursing. 2014; 20 (9)

[48] Karkada S., Nayak B., and Malathi. Awareness of Palliative Care Among Diploma Nursing Students. Indian J Palliat Care. 2011; 17(1): 20-23.

[49] Fashafsheh I, Ayed A, Sayej S, Harazneh L, Eqtait F. The Nurses' Knowledge and Attitudes towards the Palliative Care. Journal of Education and Practice.2015;6(4): 91-100.

[50] Elfeky H. Intensive Care Nurses' Knowledge \& Practices regarding Infection Control Standard Precautions at a Selected Egyptian Cancer Hospital. Journal of Education and Practice 2013; 19(4): 160-174.

[51] Wattanachote W. Communication for truth telling about dying: perception and caring behavior of intensive care unit nurses. Thesis dissertation, 1997.

[52] Budkaew J, Chumworathayi B. Knowledge and Attitudes toward Palliative Terminal Cancer Care among Thai Generalists. Asian Pac J Cancer Prev. 2013; 14 (10): 6173-80. 